\title{
Peran BPN dalam Penyertifikatan Hak Milik Atas Tanah Adat di Kantor Pertanahan Kabupaten Samosir
}

\section{The Role of BPN in the Certificate of Ownership of Customary Land at the Land Office of Samosir Regency}

\author{
Ady Hendra Lumban Tobing1), Dayat Limbong2) \& Isnaini1)* \\ 1) Program Studi Magister Ilmu Hukum, Universitas Medan Area, Indonesia. \\ 2) Program Studi Magister Hukum, Universitas Sumatera Utara, Indonesia.
}

Diterima: 22 Juli 2021; Direview: 03 Agustus 2021; Disetujui: 30 September 2021

*Coresponding Email: isnaini@staff.uma.ac.id

\begin{abstract}
Abstrak
Penelitian ini bertujuan untuk mengetahui aturan hukum, peran dan kendala yang dihadapi oleh pegawai BPN kabupaten Samosir dalam pelaksanaan pendaftaran hak milik atas tanah adat. Penelitian ini menggunakan penelitian hukum normatif. Hasil penelitian menunjukkan bahwa aturan hukum pendaftaran tanah mengacu kepada Undang-Undang No. 5 Tahun 1960 tentang Peraturan Dasar Pokokpokok Agraria serta Peraturan Pemerintah Nomor 24 Tahun 1997 tentang pendaftaran tanah. Prosedur pendaftarannya sebagai berikut: 1) Menyiapkan dokumen persyaratan, 2) Membuat dan menyampaikan surat permohonan, 3) Membayar biaya permohonan, pengukuran dan pemeriksaan tanah pemohon, 4) Membuat pengumuman melalui berita harian umum dengan jangka waktu selama 60 (enam puluh) hari, 5) Penerbitan surat keputusan (Kantah, Kanwil, atau BPN RI ), 6) Pembukuan hak dan penerbitan sertifikat. Kendala yang muncul dan dihadapi dalam pendaftaran tanah menjadi status hak milik di Kecamatan Pangururan adalah: 1) Batas tanah adat yang tidak jelas, 2) Adanya klaim dari negara atau pemerintah, 3) Kehilangan saksi atau pelaku sejarah.
\end{abstract}

Kata Kunci: Sertifikat Hak Milik; Tanah Adat; Hukum Pertanahan.

\section{Abstract}

This study aims to determine the legal rules, roles and obstacles faced by BPN employees in Samosir district in the implementation of registration of property rights on customary land. This research uses normative legal research. The results of the study indicate that the rule of law for land registration refers to Law no. 5 of 1960 concerning Basic Regulations on Agrarian Principles and Government Regulation Number 24 of 1997 concerning Land Registration. The registration procedure is as follows: 1) Prepare the required documents, 2) Prepare and submit application letters, 3) Pay the application fee, measurement and inspection of the applicant's land, 4) Make announcements through the general daily news with a period of 60 (sixty) days, 5) Issuance of decrees (Kantah, Kanwil, or BPN RI), 6) Bookkeeping of rights and issuance of certificates. Obstacles that arise and are faced in registering land as property rights in Pangururan District are: 1) Unclear customary land boundaries, 2) There are claims from the state or government, 3) Loss of witnesses or historical actors.

Keywords: Certificate of Ownership; Customary Land; Land Law.

How to Cite: Tobing, A.H.L., Limbong, D., \& Isnaini. (2021). Peran BPN dalam Penyertifikatan Hak Milik Atas Tanah Adat di Kantor Pertanahan Kabupaten Samosir. Journal of Education, Humaniora and Social Sciences (JEHSS). 4(2):1186-1198. 


\section{PENDAHULUAN}

Dalam perjalanannya sebagai sebuah Negara Merdeka, Indonesia sejak semula mengakui asas bahwa kekuasaan negara diselenggarakan berdasarkan hukum yang berlaku dan tidak berdasarkan atas kekuasaan belaka (rechsstaat bukan machsstaat). Namun dalam praktik ternyata asas ini bukan sesuatu yang mudah untuk ditepati oleh penyelenggara negara. Penyimpangan terhadap asas negara hukum oleh penguasa adalah isu utama pasca Indonesia merdeka (Asmah, 2018).

Pada zaman Hindia Belanda banyak istilah pertanahan yang cukup banyak dan ruwet, bahkan bisa dikatakan hak pertanahan pada waktu itu tidak dijamin kepastian hukumnya bagi pribumi. Istilah kepemilikan tanah seperti Domein Verklaring mempunyai arti pernyataan yang menegaskan bahwa semua tanah yang tidak dapat membuktikan kepemilikannya, maka tanah itu adalah milik negara (eigendom). Pada zaman pemerintahan Hindia Belanda, banyak tanah rakyat yang dikuasai atau diambil oleh pemerintah Hindia Belanda dengan menggunakan dasar hukum. Apabila pemilik tanah tidak dapat menunjukkan surat kepemilikannya, maka tanah menjadi milik negara atau pemerintah. Padahal kepemilikan tanah pada zaman Hindia Belanda sebagian besar tidak dilengkapi dengan tanda bukti surat kepemilikannya.

Istilah kepemilikan tanah lainnya seperti eigendom yang artinya secara harfiah diartikan bahwa hak milik tetap atas tanah merupakan hak kepemilikan yang kuat, sedangkan verponding merupakan surat tagihan pajak atas tanah sehingga Eigendom Verponding mempunyai arti surat tagihan pajak terhadap kepemilikan tanah (Iskandar, 2019)

Setelah mengalami perjalanan selama 15 tahun setelah Indonesia merdeka, pada tanggal 24 September 1960 sudah dibuat Undang-Undang Nomor 5 Tahun 1960 tentang Peraturan Dasar Pokok-pokok Agraria, atau yang lebih dikenal dengan sebutan Undang-Undang Pokok Agraria (UUPA). Dengan diundangkannya UUPA, terhapus sudah Hukum Agraria Kolonial yang mempunyai ciri-ciri, yaitu hukum agraria tersebut disusun untuk kepentingan dan keuntungan pemerintah jajahan, mempunyai sifat dualisme hukum dan bagi rakyat Indonesia tidak memberikan jaminan kepastian hukum bagi kepentingannya. Dengan adanya UUPA, terwujud sudah Hukum Agraria Nasional yang mempunyai tujuan sebagai alat untuk kesatuan (unifikasi) dan kesederhanaan dalam hukum pertanahan, dan memberikan jaminan kepastian hukum mengenai hak-hak atas tanah bagi rakyat Indonesia.

Undang-Undang Pokok Agraria (UUPA) melaksanakan ketentuan Pasal 33 ayat (3) UndangUndang Dasar 1945, dan nilai-nilai Pancasila yang terjelma dalam UUPA, juga didasarkan pada hukum adat tentang tanah, dan UUPA juga menjunjung tinggi nilai-nilai Ketuhanan Yang Maha Esa. Untuk melaksanakan ketentuan-ketentuan dalam UUPA maka dibutuhkan peraturan pelaksanaannya berupa Undang-Undang, Peraturan Pemerintah, Keputusan Presiden, Intruksi Presiden, Peraturan Menteri, dan Keputusan Menteri. Dengan dibuatnya peraturan pelaksanaan UUPA, maka apa yang dicita-citakan oleh UUPA untuk mewujudkan jaminan kepastian hukum dapat terwujud. Untuk mewujudkan jaminan kepastian hukum diperlukan upaya dalam bentuk pembuatan peraturan perundang-undangan sebagai pelaksanaan UUPA, juga diselenggarakan pendaftaran tanah terhadap seluruh bidang tanah yang ada di seluruh wilayah Indonesia (Muchsin, 2019)

Salah satu tujuan pendaftaran tanah sebagaimana yang ditetapkan dalam Pasal 3 Peraturan Pemerintah Nomor 24 Tahun 1997, adalah untuk memberikan kepastian hukum dan perlindungan kepada pemegang hak atas suatu bidang tanah., satuan rumah susun dan hak-hak lain yang terdaftar agar dengan mudah dapat membuktikan dirinya sebagai pemegang hak yang bersangkutan. Untuk memberikan kepastian hukum dan perlindungan hukum, kepada pemegang hak yang bersangkutan diberikan sertifikat hak atas tanah.

Dalam Pasal 19 Ayat (2) huruf c UUPA dinyatakan bahwa akhir kegiatan pendaftaran tanah yang diadakan oleh Pemerintah adalah pemberian surat tanda bukti hak, yang berlaku sebagai alat pembuktian yang kuat. UUPA tidak menyebut nama surat tanda bukti hak atas tanah yang didaftar. Pada Pasal 13 Ayat (3) Peraturan Pemerintah Nomor 10 Tahun 1961 dinyatakan bahwa surat tanda bukti hak atas tanah yang didaftar dinamakan sertifikat, yaitu salinan buku tanah dan surat 
ukur setelah dikumpulkan menjadi satu bersama dengan kertas sampul yang bentuknya ditetapkan oleh Menteri Agraria.

Kegiatan pendaftaran tanah untuk pertama kalinya menghasilkan surat tanda bukti hak, yang berupa sertifikat. Pengertian sertifikat menurut Pasal 1 angka 20 Peraturan Pemerintah Nomor 24 Tahun 1997, Ayat (2) huruf c UUPA untuk hak atas tanah, hak pengelolaan, tanah wakaf, hak milik atas satuan rumah susun dan hak tanggungan yang masing-masing sudah dibukukan dalam buku tanah yang bersangkutan (Santoso, 2010)

Secara etimologi sertifikat berasal dari bahasa Belanda, yaitu certificat yang artinya surat bukti atau surat keterangan yang membuktikan tentang sesuatu. Jadi kalau dikatakan sertifikat tanah adalah surat keterangan yang membuktikan hak seseorang atas sebidang tanah, atau dengan kata lain keadaan tersebut menyatakan bahwa ada seseorang yang memiliki bidang-bidang tanah tertentu dan pemilikan itu mempunyai bukti yang kuat berupa surat yang dibuat oleh instansi yang berwenang (Lubis, 2017).

Jenis hak tanah yang dinamakan hak milik merupakan hak yang paling kuat di antara hakhak atas tanah yang lainnya, dan secara yuridis jenis hak milik ini akan menjadi hak yang tidak kuat apabila tidak dilengkapi dengan pembuktian yang dinamakan alat bukti sertifikat (Iskandar, 2019). Istilah hak milik berasal dari bahasa Belanda yaitu eigendom, sedangkan dalam bahasa Inggris disebut dengan istilah ownership (Anatami, 2017). Menurut Simanjuntak hak milik adalah hak untuk menikmati kegunaan sesuatu kebendaan dengan leluasa, dan untuk berbuat bebas terhadap kebendaan itu dengan kedaulatan sepenuhnya, asal tidak bertentangan dengan UndangUndang atau peraturan umum yang ditetapkan oleh suatu kekuasaan yang berhak menetapkannya, dan tidak mengganggu hak-hak orang lain (Simanjuntak, 2015).

Dalam hukum adat terdapat hak penguasaan atas tanah yang tertinggi yang disebut dengan Hak Ulayat yaitu hak persekutuan masyarakat hukum adat atas tanah dalam suatu wilayah teritorial atau wilayah geneologis. Hak ulayat ini mengandung aspek keperdataan dan aspek publik. Aspek keperdataan yakni bahwa di wilayah ulayat di samping hak-hak bersama masyarakat juga terdapat hak-hak perseorangan, sedangkan aspek publik yakni bahwa hak ulayat adalah hak kepunyaan bersama dari masyarakat hukum adat yang didalamnya mengandung hakhak, kewajiban-kewajiban dan wewenang dari penguasa adat untuk mengelola, mengatur atas tanah. Oleh karena itu, maka hukum adat mengenal Hukum Tanah Perdata dan Hukum Tanah Publik (Arba, 2019).

Menurut peraturan perundang-undangan yang berlaku, bukti kepemilikan lain untuk tanahtanah adat adalah surat pernyataan pemilik atau penggarap tanah dan surat pemberian hak oleh pejabat yang berwenang. Untuk luar pulau Jawa, kedua bukti kepemilikan tersebut dipakai untuk mendapatkan surat tanah atau surat keterangan tanah. Meskipun demikian, surat-surat tersebut bukanlah bukti kepemilikan hak atas tanah melainkan hanya sebagai bukti pembayaran pajak atas tanah, yang sekarang disebut tanda bukti pembayaran pajak.

Prosedur mengajukan permohonan hak atas tanah tergantung dari hak yang akan diletakkan di atasnya. Dalam Peraturan Pemerintah Nomor 24 Tahun 1997 tidak ada ketentuan yang memerintahkan pendaftaran hak ulayat. Hak ulayat tidak dimasukkan ke dalam golongan objek pendaftaran tanah. Meski demikian Pasal 5 ayat 2 Peraturan Menteri Negara Agraria/Kepala BPN Nomor 5 Tahun 1999 menyebutkan mengenai keberadaan tanah ulayat masyarakat hukum adat yang masih ada, dinyatakan dalam peta dasar pendaftaran tanah dengan membubuhkan suatu tanda kartografi. Apabila memungkinkan, menggambarkan batas-batasnya serta mencatatnya dalam daftar tanah (Yasin, 2014).

Hukum adat mengenai tanah adat dalam etnik Batak Toba, didaerah kabupaten Samosir menjadi fokus utama dalam takaran ilmiah. Etnik Batak Toba yang hidup di daerah Somosir pada hakekatnya adalah kumpulan komunitas adat dan umumnya adalah petani yang mengarap tanah pertanian. Tidak salah kalau masyarakat Batak Toba di Samosir berbeda perspektif mengenai tanah dengan etnik lain di Indonesia bahkan dengan konsep hukum negara dengan tanah adat.

Dengan adanya perkembangan pembangunan daerah Samosir berdasarkan pembentukan pemerintah daerah semakin meningkatkan taraf hidup masyarakat kearah lebih modern sehingga 1188 http://mahesainstitute.web.id/ojs2/index.php/jehss

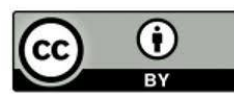


setiap sisi kehidupan pada masyarakat mulai meninggalkan gaya hidup terdahulu. Hal ini terlihat dari beberapa perkara hukum dalam masyarakat yang diselesaikan melalui jalur peradilan yang disediakan pemerintah.

Adapun perkara hukum yang terjadi di masyarakat adalah banyaknya konflik mengenai tanah yang digunakan sebagai objek pembangunan yang tidak berdasarkan sisi hukum adat. Sehubungan dengan keadaan konflik yang terjadi di daerah Samosir telah menimbulkan perkara hukum masyarakat yang tinggal di daerah Samosir, sehingga proses pembangunan didaerah Samosir tersebut mengalami perlambatan atas program pemerintah. Bentuk kasus yang terjadi adalah sengketa tanah yang disebabkan oleh tanah adat yang tidak didaftarkan oleh ahli waris di Badan Pertanahan Nasional Kabupaten Samosir. Sengketa tanah yang umum terjadi adalah pengelolaan tanah yang dikelola tanpa persetujuan pemilik tanah dialihkan secara sepihak. Sengketa bisa terjadi dikarenakan adanya pihak luar sebagai pendatang ke daerah tersebut, menyatakan hak atas tanah secara sepihak dengan ijin pakai dari masyarakat yang bukan pemilik sah tanah tersebut (Siregar).

Dalam kehidupan masyarakat suku Batak Toba yang bermukim di Kabupaten Samosir berdasarkan informasi dari kantor pertanahan mengenai perkara pendaftaran tanah menunjukkan bahwa masih banyak tanah-tanah yang diperoleh masyarakat melalui warisan (ahli waris) namun letak lokasi tanah-tanah (warisan) tersebut hanya diinformasikan secara lisan dari nenek moyang berupa klaim atas tanah yang diakui masyarakat setempat, akan tetapi belum didaftarkan di Kantor Pertanahan Daerah Kabupaten Samosir.

\section{METODE PENELITIAN}

Penelitian ini menggunakan penelitian hukum Normatif, yaitu penelitian yang mengacu kepada norma-norma hukum yang terdapat dalam peraturan perundang-undangan yang berlaku sebagai pijakan normatif (Amiruddin, 2006, p.118.). Meuwissen memandang bahwa istilah ilmu hukum normatif sama dengan istilah ilmu hukum dogmatik, apabila orang ingin menonjolkan karakter normatifnya dari ilmu hukum dogmatik seperti apa yang dipahami oleh Kelsen. Sementara P. Scholten memandang bahwa ilmu hukum normatif tidak saja memaparkan norma deskriptif (beschrijven) tetapi juga menormai atau mengkaidahi (voorschrijven) sebagai tindakan yang berdimensi politik praktikal. Dalam kondisi seperti itu, menurut Meuwissen, ilmu hukum normatif mempunyai tugas pokok untuk mengarahkan, menganalisis, mensistematisasi, menginterpretasi dan menilai hukum positif. Hal itu menunjukkan bahwa ilmu hukum normatif mempunyai dimensi majemuk yakni selain dimensi menjelaskan secara tuntas tentang norma hukum juga berupaya memberi dimensi normatif-kontemplatif untuk dijadikan pedoman dalam praktik hukum (Diantha, 2019).

Sumber dan jenis data dalam penelitian hukum ini dilakukan dengan pengumpulan datadata primer dan data sekunder yaitu: Data Primer: Data primer ini diperoleh dengan cara mengadakan penelitian lapangan dengan mengadakan wawancara, yaitu cara untuk memperoleh dengan cara bertanya secara langsung kepada responden yang telah ditetapkan sebelumnya. Tipe wawancara yang dilakukan adalah wawancara tidak berstruktur yaitu wawancara yang dilakukan dengan tidak dibatasi oleh waktu dan daftar urutan pertanyaan, tetapi tetap berpegang pada pokok penting permasalahan yang sesuai dengan tujuan wawancara. Data Sekunder: Data sekunder diperoleh melalui studi kepustakaan yaitu literatur-literatur para ahli hukum dan peraturan perundang-undangan yang berhubungan dengan objek dan permasalahan yang diteliti. Data-data sekunder meliputi: Bahan hukum primer yaitu peraturan perundang-undangan antara lain:Undang-Undang Nomor 5 Tahun 1960 tentang Peraturan Dasar Pokok-Pokok Agraria; Peraturan Pemerintah Nomor 10 Tahun 1961 tentang Pendaftaran Tanah; Peraturan Pemerintah Nomor 24 Tahun 1997 tentang Pendaftaran Tanah; Peraturan Menteri Agraria/Kepala Badan Pertanahan Nomor 3 Tahun 1997 tentang Ketentuan Pelaksanaan Peraturan Pemerintah Nomor 24 Tahun 1997; Peraturan Menteri Negara Agraria/Kepala Bandan Pertanahan Nomor 7 Tahun 1998 tentang Kewenangan Menanda Tangani Buku Tanah, Surat Ukur, dan Sertifikat. 
Metode pendekatan yang akan diterapkan dalam penelitian hukum yang akan dilakukan oleh peneliti yaitu pendekatan Undang-Undang (Statute Approach) dan metode pendekatan kasus (Case Approach). Jika metode pendekatan yang dipergunakan dalam penelitian adalah metode pendekatan normatif, yang secara deduktif, dimulai analisis terhadap pasal-pasal yang mengatur hal-hal yang menjadi permasalahan di atas, metode pendekatan ini digunakan dengan mengingat permasalahan yang diteliti berdasarkan pada peraturan-peraturan perundang-undangan yaitu hubungan peraturan satu dengan peraturan lain serta kaitannya dengan penerapannya dalam praktek (Nasution, 2008).

Alat pengumpulan data yang digunakan dalam penelitian ini yakni dalam hal mengumpulkan data primer dengan menggunakan metode wawancara dengan pegawai kantor ATR-BPN Kabupaten Samosir yang dalam hal ini akan memberikan informasi yang memiliki wewenang dan kapasitas dalam memberikan informasi ataupun sebagai narasumber. Sedangkan data sekunder akan dikumpulkan dengan menggunakan alat pengumpulan data berupa studi kepustakaan (library research) berupa bahan hukum peraturan perundang-undangan dan bahan tertulis lainnya yakni dengan mencari, serta mengumpulkan data tersebut kemudian mengkaji dan menganalisis sesuai dengan objek penelitian.

Analisis diartikan sebagai penyelidikan terhadap suatu peristiwa untuk mengetahui keadaan yang sebenarnya, sebab musabab, atau duduk perkaranya. Analisis data yaitu penelaahan dan penguraian atas data hingga menghasilkan kesimpulan. Analisis data berisi uraian tentang caracara analisis, yakni bagaimana memanfaatkan data yang terkumpul untuk dipergunakan dalam memecahkan masalah dalam penelitian yang dilakukan (Butar, 2018, p. 146). Setelah bahan hukum terkumpul kemudian dilakukan analisis untuk mendapatkan argumentasi akhir yang berupa jawaban terhadap permasalahan penelitian. Untuk itu setidaknya dapat digunakan empat macam teknik analisis yakni: deskripsi, komparasi, evaluasi dan argumentasi. Data yang telah dikumpulkan dengan studi kepustakaan dan wawancara tersebut selanjutnya dianalisis dengan mempergunakan metode analisis kualitatif yaitu penelitian tentang riset yang bersifat deskriptif (Diantha, 2019).

\section{HASIL DAN PEMBAHASAN Pengaturan Pendaftaran Tanah}

Pada tanggal 24 September 1960 disahkan Undang-Undang No. 5 Tahun 1960 tentang Peraturan Dasar Pokok-pokok Agraria, LNRI Tahun 1960 No. 104-TLNRI No. 2043. UndangUndang ini lebih dikenal dengan sebutan Undang-Undang Pokok Agraria (UUPA). Sejak diundangkan UUPA, berlakulah Hukum Agraria Nasional yang mencabut peraturan dan keputusan yang dibuat pada masa Pemerintahan Hindia Belanda, antara lain Agrarische wet 1870 No. 55 dan Agrarische Belsuit Stb. 1870 No. 118 (Santoso, 2010, p. 1.)

Tujuan disahkannya UUPA sebagaimana yang dimuat dalam Penjelasan umumnya, yaitu: Meletakkan dasar-dasar bagi penyusunan Hukum Agraria Nasional, yang merupakan alat untuk membawakan kemakmuran, kebahagiaan dan keadilan bagi Negara dan rakyat, terutama rakyat tani, dalam rangka masyarakat adil dan makmur; Meletakkan dasar-dasar untuk mengadakan kesatuan dan kesederhanaan hukum pertahanan; Meletakkan dasar-dasar untuk memberikan kepastian hukum mengenai hak-hak atas tanah bagi rakyat seluruhnya.

Pemberian jaminan kepastian hukum mengenai hak-hak atas tanah bagi seluruh rakyat Indonesia, yang menjadi salah satu tujuan disahkannya UUPA dapat terwujud melalui dua upaya, yaitu: Tersedianya perangkat hukum yang tertulis, lengkap dan jelas yang dilaksanakan secara konsisten sesuai dengan jiwa dan ketentuan-ketentuannya; Penyelenggaran pendaftaran tanah yang memungkinkan bagi pemegang hak atas tanah untuk dengan mudah membuktikan hak atas tanah yang dikuasainya, dan bagi pihak yang berkepentingan, seperti calon pembeli dan calon kreditor, untuk memperoleh keterangan yang diperlukan mengenai tanah yang menjadi objek perbuatan hukum yang akan dilakukan, serta bagi Pemerintah untuk melaksanakan kebijaksanaan pertanahan (Santoso, 2020) 
Pendaftaran tanah yang bertujuan untuk memberikan jaminan kepastian hukum dikenal dengan sebutan Rechs Cadaster atau Legal Cadaster. Jaminan kepastian hukum yang hendak diwujudkan dalam pendaftaran tanah ini, meliputi kepastian status hak yang didaftar, kepastian subjek hak, dan kepastian objek hak (Yasim, 2017).

Pendaftaran tanah ini menghasilkan Sertifikat sebagai tanda bukti haknya. Kebalikan dari pendaftaran tanah yang Rechts Cadaster, adalah Fiscaal Cadaster, yaitu pendaftaran tanah yang bertujuan untuk menetapkan siapa yang wajib membayar pajak atas tanah. Pendaftaran tanah ini menghasilkan surat tanda bukti pembayaran pajak atas tanah, yang sekarang dikenal dengan sebutan Surat Pemberitahuan Pajak Terutang Pajak Bumi dan Bangunan (SPPT PBB).

UUPA mengatur pendaftaran tanah yang bertujuan untuk memberikan jaminan kepastian hukum. Pendaftaran tanah ini menjadi kewajiban bagi pemerintah maupun pemegang hak atas tanah. Ketentuan tentang kewajiban bagi Pemerintah untuk menyelenggarakan pendaftaran tanah di seluruh wilayah Republik Indonesia diatur dalam Pasal 19 UUPA, yaitu:

Untuk menjamin kepastian hukum oleh Pemerintah diadakan pendaftaran tanah diseluruh wilayah Republik Indonesia menurut ketentuan-ketentuan yang diatur dengan Peraturan Pemerintah.

Pendaftaran tersebut dalam Ayat 1 pasal ini meliputi: Pengukuran, perpetaan, dan pembukuan tanah; Pendaftaran hak-hak atas tanah dan peralihan hak-hak tersebut; Pemberian surat-surat tanda bukti hak, yang berlaku sebagai alat pembuktian yang kuat; Pendaftaran tanah diselenggarakan dengan mengingat keadaan negara dan masyarakat, keperluan lalu lintas sosial ekonomi serta kemungkinan penyelenggaraannya, menurut pertimbangan Menteri Agraria.

Dalam Peraturan Pemerintah diatur biaya-biaya yang bersangkutan dengan pendaftaran termaksud dalam ayat 1 diatas, dengan ketentuan bahwa rakyat yang tidak mampu dibebaskan dari pembayaran biaya-biaya tersebut (Santoso, 2010).

Undang-Undang ini secara resmi diberi nama UU No 5 Tahun 1960 tentang Peraturan Dasar Pokok-pokok Agraria, yang mengatur mengenai tentang hak-hak atas tanah, air, dan udara. Hal tersebut juga meliputi aturan dasar dan ketentuan penguasaan, pemilikan, penggunaan atau pemanfaatan sumber daya agraria nasional di Indonesia, pendaftaran tanah, ketentuan-ketentuan pidana dan ketentuan peralihan.

Lebih lanjut, Undang-Undang No 5 Tahun 1960 adalah penegasan bahwa penguasaan dan pemanfaatan atas tanah, air, dan udara harus dilakukan berdasarkan asas keadilan dan kemakmuran bagi pembangunan masyarakat yang adil dan makmur. Hal tersebut sejalan dengan UUD 1945 Pasal 33 Ayat 3 yang berbunyi "Bumi dan air dan kekayaan alam yang terkandung di dalamnya dikuasai oleh negara dan dipergunakan untuk sebesar-besar kemakmuran rakyat". (UUPA juga mengatur kewajiban bagi pemegang Hak Milik, pemegang Hak Guna Usaha, dan pemegang Hak Guna Bangunan untuk mendaftarkan hak atas tanahnya. Kewajiban bagi pemegang Hak Milik atas tanah untuk mendaftarkan tanahnya diatur dalam Pasal 23 UUPA, yaitu: Hak Milik, demikian pula setiap peralihan, hapusnya dan pembebanannya dengan hak-hak lain harus didaftarkan menurut ketentuan-ketentuan yang dimaksud dalam Pasal 19; Pendaftaran termaksud dalam Ayat 1 merupakan alat pembuktian yang kuat mengenai hapusnya hak milik serta sahnya peralihan dan pembebanan hak tersebut.

Kewajiban bagi pemegang Hak Guna Usaha untuk mendaftarkan tanahnya diatur dalam Pasal 32 UUPA, yaitu: Hak Guna Usaha, termasuk syarat-syarat pemberiannya, demikian juga setiap peralihan dan penghapusan tersebut, harus didaftarkan menurut ketentuan-ketentuan yang dimaksud dalam Pasal 19; Pendaftaran termaksud dalam Ayat 1 merupakan alat pembuktian yang kuat mengenai peralihan serta hapusnya Hak Guna Usaha, kecuali dalam hak-hak itu hapus karena jangka waktunya berakhir.

Kewajiban bagi pemegang Hak Guna Bangunan untuk mendaftarkan tanahnya diatur dalam Pasal 38 UUPA, yaitu: Hak Guna Bangunan, termasuk syarat-syarat pemberiannya, demikian juga setiap peralihan dan hapusnya hak tersebut harus didaftarkan menurut ketentuan-ketentuan yang dimaksud dalam Pasal 19; Pendaftaran termaksud dalam Ayat 1 merupakan alat pembuktian yang 
kuat mengenai hapusnya Hak Guna Bangunan serta sahnya peralihan hak tersebut, kecuali dalam hak itu hapus karena jangka waktunya berakhir.

UUPA juga mengatur pendaftaran Hak Pakai atas tanah, sebagaimana yang diatur dalam Pasal 41 UUPA, yaitu "Hak Pakai adalah hak untuk menggunakan dan/atau memungut hasil dari tanah yang dikuasai langsung oleh negara atau tanak milik orang lain, yang memberi wewenang dan kewajiban yang ditentukan dalam keputusan pemberiannya oleh pejabat yang berwewenang memberikannya atau dalam perjanjian dengan pemilik tanahnya, yang bukan perjanjian sewa menyewa atau perjanjian pengolahan tanah, segala sesuatu asal tidak bertentangan dengan jiwa dan ketentuan-ketentuan Undang-Undang ini.

\section{Pelaksanaan Pendaftaran Hak Milik Atas Tanah Adat di Kantor Pertanahan Kabupaten Samosir}

Pendaftaran tanah bertujuan untuk menjamin kepastian hukum pemegang hak atas tanah dan pihak lain yang berkepentingan dengan tanah tersebut. Penyelenggara pendaftaran tanah adalah BPN. Pendaftaran tanah dilakukan di kantor pertanahan yang berada di kabupaten/kotamadya. Dalam melaksanakan tugasnya BPN dibantu oleh Pejabat Pembuat Akta Tanah (Yasim, 2017). Pejabat umum yang akan diberi kewenangan untuk membuat akta-akta otentik mengenai perbuatan hukum tertentu mengenai hak atas tanah atau Hak Milik Atas Satuan Rumah Susun adalah PPAT (Pasal 2 PP Nomor 37 Tahun 1998 tentang Pejabat Pembuat Akta Tanah dan Pasal 1 Peraturan Kepala BPN Nomor 1 Tahun 2006 tentang Ketentuan Pelaksanaan PP Nomor 37 Tahun 1998 tentang Pejabat Pembuat Akta Tanah).

Pendaftaran tanah untuk pertama kali dilakukan untuk tanah-tanah yang belum didaftarkan (belum pernah disertifikatkan) sesuai dengan ketentuan PP Nomor 10 Tahun 1961 dan PP Nomor 24 Tahun 1997 tentang Pendaftaran Tanah. Ada du acara untuk memperoleh sertifikat hak atas tanah, yaitu: Melalui pendaftaran tanah sporadic, Pendaftaran tanah dilakukan untuk pertama kali terhadap satu atau beberapa objek pendaftaran tanah pada suatu desa atau kelurahan. Inisiatif pendaftaran tanah atau sertifikasi berasal dari pemilik tanah sebagai pemohon sertifikat yang bisa dilakukan secara perseorangan atau bersama-sama. Pemohon dapat melakukan penyertifikatan tanah sendiri atau melalui orang yang diberikan kuasa (PPAT) sebagai pemohon. Melalui pendaftaran tanah sistematis, Pendaftaran tanah dilakukan pertama kali yang dilakukan secara serentak yang meliputi semua objek pendaftaran tanah yang belum didaftar pada suatu desa atau kelurahan. Inisiatif pendaftaran tanah atau sertifikasi berasal dari pemerintah yang mencakup satu atau sebagian wilayah desa atau kelurahan. Menteri Agraria atau Kepala BPN membentuk Panitia ajudikasi yang terdiri atas staf Badan Pertanahan Nasional dan aparat desa atau kelurahan untuk melakukan penyertifikatan tanah-tanah penduduk yang belum bersertifikat.

Sertifikat adalah surat tanda bukti hak atas, hak pengelolaan, tanah wakaf, hak milik atas satuan rumah susun dan hak tanggung jawab yang masing-masing sudah dibukukan dalam buku tanah yang bersangkutan (Pasal 1 ayat (20) PP Nomor 24 Tahun 1997). Sertifikat merupakan surat tanda bukti hak yang berlaku sebagai alat pembuktian yang kuat. Sertifikat diterbitkan agar pemegang hak atas tanah mencantumkan hal-hal sebagai berikut: Jenis ha katas tanah; Pemegang hak; Keterangan fisik tentang tanah; Beban di atas tanah; Peristiwa hukum yang terjadi dengan tanah.

Pemohon sertifikat hak atas tanah dapat mengurus sertifikat dengan cara mengajukan permohonan kepada BPN setelah melengkapi surat-surat yang diperlukan. Selanjutnya BPN dapat menerbitkan sertifikasi atas pemohon setelah pemohon memenuhi syarat-syarat yang diperlukan. Alasan masyarakat mengurus sertifikat atas kemauan sendiri antara lain karena menyadari kegunaan sertifikat, memperkuat pembuktian hak atas tanah, agar membebani hak atas tanah, atau permintaan pihak lain, misalnya bank, jika terkait dengan permohonan kredit.

Adapun aturan penerbitan sertifikat adalah sebagai berikut: Sertifikat diterbitkan untuk kepentingan pemegang hak yang bersangkutan sesuai dengan data fisik dan yuridis yang telah didaftar dalam buku tanah; Sertifikat hanya boleh diserahkan kepada pihak yang namanya

1192. http://mahesainstitute.web.id/ojs2/index.php/jehss mahesainstitut@gmail.com

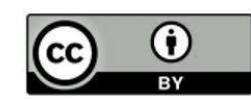


tercantum dalam buku tanah, sebagai pemegang hak, atau kepada pihak lain yang dikuasakan olehnya.

Mengenai hak atas tanah atau hak milik atas satuan rumah susun kepunyaan bersama, beberapa orang, atau badan hukum, diterbitkan satu sertifikat, yang diterimakan kepada salah satu pemegang hak bersama atas penunjukan tertulis para pemegang hak bersama yang lain. Dapat saja diterbitkan sertifikat sebanyak jumlah pemegang hak bersama untuk diberikan kepada tiap pemegang hak bersama yang bersangkutan, yang memuat nama dan besarnya bagian masingmasing dari hak tersebut.

Tanah bekas hak milik adat adalah tanah yang dikuasai masyarakat dalam keadaan belum bersertifikat dan ditandai dengan surat girik. Bukti kepemilikan hak atas tanah bekas hak milik adat di desa adalah petuk pajak: girik, ketitir, dan pipil. Ketiga istilah tersebut popular digunakan di Jawa dari dulu sampai sekarang. Ada istilah "cap singa" yang ditemukan di Jawa Barat bahkan Kalimantan. Sedangkan untuk tanah bekas hak milik adat di kota besar adalah verponding Indonesia. Menurut peraturan perundang-undangan yang berlaku, bukti kepemilikan lain untuk tanah-tanah adat adalah surat pernyataan pemilik atau penggarap tanah dan surat pemberian hak oleh pejabat yang berwenang. Untuk luar pulau Jawa, kedua bukti kepemilikan tersebut dipakai untuk mendapatkan surat tanah atau surat keterangan tanah.

Meskipun demikian, surat-surat tersebut bukanlah merupakan bukti kepemilikan hak atas tanah melainkan hanya sebagai bukti pembayaran pajak atas tanah, yang sekarang disebut tanda bukti pembayaran pajak. Untuk tanah-tanah seperti itu masih dapat dilakukan jual-beli di hadapan PPAT atau permohonan pendaftaran tanah untuk pertama kali ke kantor pertanahan kabupaten atau kotamadya. Selain untuk jual-beli tanah dan pendaftaran tanah, tanah-tanah dengan bukti kepemilikan tersebut dibutuhkan juga dalam konversi hak atas tanah, penggandaan tanah dan pemberian izin atas tanah atau izin membuka tanah. Adapun syarat-syarat untuk mengajukan permohonan sertifikat, yakni: Bukti pembayaran pajak: surat gitik, petuk pajak bumi, pipil atau ketitir; Surat perolehan tanah (AJB, jika terjadi jual-beli tanah, keterangan waris, hibah); Kuitansi jual-beli; Surat keterangan riwayat tanah; Surat pernyataan bahwa tanah tersebut tidak dalam sengketa; Identitas pemohon ha katas tanah (KTP, Kartu Keluarga, Akta Pendirian Badan Hukum); Surat Pemberitahuan PAjak Terutang dan Surat Tanda Terima Setoran Pajak Bumi dan Bangunan (PBB), biasanya sepuluh tahun terakhir; Bukti bayar Bea Perolehan Hak atas Tanah dan Bangunan (BPHTB); h.Surat permohonan pengukuran tanah (formulir ini diperoleh di kantor pertanahan setempat); Surat kuasa bermaterai jika pengurusan sertifikat dikuasakan kepada orang lain; Surat pernyataan pemasangan tanda batas (formulir ini diperoleh di kantor pertanahan setempat).

Setelah surat-surat di atas sudah lengkap, BPN akan meneliti dokumen tersebut dan selanjutnya melakukan pengukuran atas tanah yang bersangkutan. Setelah itu, BPN akan mempublikasikan data fisik dan data yuridis tanah yang bersangkutan di kantor pertanahan dan kantor desa atau kelurahan setempat selama 60 hari sebelum menerbitkan sertifikat.

Tanah adat (tanah ulayat) adalah tanah yang berada dalam penguasaan masyarakat hukum adat. Seiring dengan perkembangan zaman dan pembangunan yang memerlukan tanah, pemerintah dan pengusaha mulai mengincar tanah ulayat untuk membangun berbagai macam proyek infrastruktur dan industry pertanian ekstraktif (Soerojo, 2004).

Prosedur untuk memperoleh tanah ulayat tidak seperti prosedur mendapatkan tanah hak seperti hak milik, HGB, dan HGU. Jika ada pihak yang ingin memperoleh tanah ulayat, ia harus mengadakan musyawarah terlebih dahulu dengan ketua atau perwakilan dari masyarakat hukum adat untuk mencapai kesepakatan mengenai pelepasan hak (Darwis, 2017).

Prosedur mengajukan permohonan hak atas tanah tergantung dari hak yang akan diletakkan di atasnya. Dalam PP Nomor 24 Tahun 1997 tidak ada ketentuan yang memerintahkan pendaftaran hak ulayat. Hak ulayat tidak dimasukkan ke dalam golongan objek pendaftaran tanah. Meski demikian, Pasal 5 ayat 2 Peraturan Menteri Negara Agraria/Kepala BPN Nomor 5 Tahun 1999 menyebutkan mengenai keberadaan tanah ulayat masyarakat hukum adat yang masih ada, dinyatakan dalam peta dasar pendaftaran tanah yang membubuhkan suatu tanda kartografi. 
Apabila memungkinkan, menggambarkan batas-batasnya serta mencantumkan dalam daftar tanah.

\section{Kendala yang Dihadapi BPN Dalam Pendaftaran Hak Atas Tanah Adat}

Batas tanah adat yang tidak jelas. Salah satu bukti kepemilikan tanah adat oleh satu kelompok masyarakat ulayat adalah adanya batas yang jelas dengan tanah milik suku lain atau tanah Negara. Batas tanah yang jelas akan memberi legitimasi kepada masyarakat suku lain atau pemerintah, untuk mengakui keberadaan tanah yang dimiliki kelompok suku atau ulayat tertentu.

Berdasarkan struktur masyarakat, hak ulayat merupakan bagian yang tidak terpisahkan dari masyarakat hukum. Menurut R. Van Dijk, hukum tanah di Indonesia dalam segala hal pernyataannya kuat terikat pada bangunan corak dari persekutuan territorial, ialah dasar bagi kesatuan anggota-anggota persekutuan.

Menurut Van Vollenhoven, hak ulayat dimiliki suatu masyarakat hukum adat (suku, desa, serikat desa) untuk menguasai seluruh isinya dan lingkungan wilayahnya. Dengan demikian, subjek hak ulayat adalah masyarakat hukum adat, baik yang tunggal atau persekutuan daerah, tetapi tidak merupakan hak dari individu, merupakan pula hak dari famili. Misalnya, di Sumatera Barat sebelah utara hak adalah nagari. Di Ambon merupakan hak dari family (dati). Demikian juga, Boedi Harsono, pemegang hak ulayat adalah masyarakat hukum adat, bukan perorangan. Ada yang bersifat teritorial, karena para warganya bertempat tinggal di wilayah yang sama, seperti nagari di Minangkabau. Ada pula yang bersifat genealogis yang para warganya terikat oleh pertalian daerah seperti suku dan kaum.

Hak ulayat yang dikenal di kalangan masyarakat hukum adat di berbagai daerah dengan nama yang berbeda-beda merupakan penguasaan yang tertinggi atas tanah dalam hukum adat, yang meliputi semua tanah termasuk dalam luingkungan wilayah suatu masyarakat hukum adat tertentu, yang merupakan tanah kepunyaan bersama warganya. Hak ulayat mengandung 2 (dua) unsur, yaitu unsur hukum perdata, sebagai hak kepemilikan bersama para warga masyarakat hukum adat yang bersangkutan atas tanah ulayat, yang dipercaya berasal mula-mula sebagai peninggalan nenek moyang mereka dan merupakan karunia suatu kekuatan ghaib, sebagai pendukung utama kehidupan dan penghidupan serta lingkungan hidup (lebensraum) seluruh warga masyarakat hukum adat. Unsur hukum publik, yaitu kewenangan untuk mengelola dan mengatur peruntukkan dan penggunaan, dan penguasaan tanah ulaya tersebut, baik dalam hubungan intern dengan para warganya sendiri maupun ekstern dengan orang-orang bukan warga atau orang luar (Rosnidar, 2017).

Berdasarkan uraian di atas, subjek hak ulayat adalah masyarakat hukum adat, yaitu nagari, suku, kaum desa. Masyarakat hukum dimaksud merupakan warga dalam kelompok sebagai nagari, desa. Masyarakat hukum adat dengan berbagai nama menurut bahasa daerah masing-masing adalah sekelompok orang yang terkait oleh tatanan hukum adatnya sebagai warga bersama suatu persekutuan hukum karena kesamaan tempat tinggal (territorial) ataupun atas dasar keturunan atau hubungan keluarga (genealogis).

Berdasarkan rumusan hak ulayat sebagaimana dikemukakan terdahulu bahwa masyarakat hukum adat atas tanah yang tidak terbatas atas tanah tetapi segala sesuatu yang ada di atas tanah. Objek hak ulayat pada umumnya adalah meliputi semua tanah (daratan, pantai, sungai, danau yang terletak dalam wilayah masyarakat hukum adat, dan hak ulayat yang menyangkut tanah, air, tumbuh-tumbuhan dan binatang liar).

Masyarakat hukum adat mempunyai cara tertentu untuk memelihara dan mempertahankan hak ulayatnya. Pertama, dengan menetapkan batas-batas di sekeliling wilayahnya biasanya dengan batas-batas fisik, berupa batu, penanaman pohon, bukti, sungai, dan sebagainya. Kedua, dengan menunjuk pejabat-pejabat tertentu, jarring (Minangkabau), terusan (Minahasa), kepala kewang (Ambon), lelipis (Bali), di samping itu diadakan pula patrol perbatasan.

Menurut Ter Haar, batas-batas hak ulayat ada yang tegas, yaitu sebagai akibat pertemuan antara persekutuan hukum dengan persekutuan lain, dan batas-batas yang samar-samar yaitu berupa tanah kosong yang luas. Pengairan yang dikuasai hak ulayat adalah kali, danau, jalur laut 1. http://mahesainstitute.web.id/ojs2/index.php/jehss mahesainstitut@gmail.com

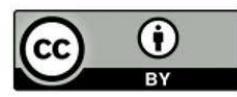


sepanjang-panjang. Sedangkan tumbuhan yang dimaksud adalah tumbuhan atau tanaman yang tumbuh secara liar (pohon buah-buahan, pohon kayu untuk pertukangan atau kayu bakar, dan sebagainya).

Boedi Harsono berpendapat bahwa tidak mudah untuk mengetahui secara pasti batas-batas tanah ulayat. Sedangkan masyarakat genealogi dapat diketahui dengan membedakan mana yang termasuk tanah bersama. Ketidakjelasan ukuran yang digunakan dalam menentukan batas-batas hak ulayat sering menimbulkan konflik di bidang pertanahan hukum adat. Untuk menentukan batas-batas hak ulayat diperlukan kerja sama masyarakat hukum terutama yang berbatasan. Batas-batas merupakan yang sangat penting dalam menentukan eksistensi masyarakat hukum adat atau hak ulayat. Karena itu perlu perumusan yang jelas mengenai batas-batas tersebut, karena masing-masing daerah berbeda-beda. Konflik yang terjadi karena ketidakjelasannya tidak terjadi kalau ada ketegasan-ketegasan hukum dalam bidang pertanahan.

Hampir sebagian tanah yang dimiliki oleh masyarakat adat suku Batak Toba di kecamatan Pangururan Kabupaten Samosir, tidak memiliki batas kepemilikan serta luas tanah yang jelas. Batas tanah adat umumnya ditandai dengan batas alam seperti pepohonan, tumpukan batu dan gundukan tanah serta bukit atau gunung tertentu.

Batas tanah suku dengan menggunakan batas alam ini dapat dimanipulasi oleh suku tertentu dengan dihancurkan atau dipindahkan. Misalnya pohon atau batu bisa dimusnahkan atau dipindahkan oleh suku tertentu dari tempat lain ketempatnya semula atau untuk memperluas tanah sukunya. Ada yang mengklaim bahwa pohon atau kayu atau tebing adalah muncul secara alamiah, karena itu tidak bisa dijadikan bukti batas tanah suku.

Karena batas tanah adat atau Suku Batak Toba hanya dengan menggunakan batas alam yang tidak jelas, maka di Kecamatan Pangururan Kabupaten Samosir selalu terjadi pengklaiman antara masyarakat lain di atas satu bidang tanah. Sering juga tidak saling mengakui batas tanah ulayat yang satu dengan tanah ulayat yang lainnya. Akibat saling mengklaim dan tidak mengakui ini, maka perang atau bentrok fisik antara suku yang menyebabkan korban nyawa dan kerusakan harta benda sering tidak terhindarkan.

Adanya klaim dari negara atau pemerintah. Banyak tanah milik masyarakat suku atau milik masyarakat ulayat yang diklaim oleh Pemerintah sebagai milik Negara tanpa melalui prosedur hukum yang jelas. Penggunaan tanah Negara bermula pada zaman Hindia Belanda sesuai dengan konsep hubungan antara penguasa (Hindia Belanda) dengan tanah yang berupa hubungan kepemilikan, maka dikeluarkan suatu pernyataan yang terkenal dengannama Domein Verklaring pada Tahun 1870, yang secara singkat menyatakan bahwa: Semua tanah yang pihak lain tidak dapat membuktikan sebagai hak eigendomnya adalah domein (milik) Negara.

Terhadap hak masyarakat hukum adat sepanjang sejarah Indonesia selalu menunjukkan perlakuan yang mengecewakan. Keadaan tersebut berupa pelecehan, penghargaan semu, dan salah pengertian terhadap ajaran dan prinsip hukum adat. Keadaan semacam itu, menurut Moh. Koesnoe terjadi sejak zaman kerajaan dan diteruskan oleh kekuasaan pemerintah kolonial pada masa silam. Keadaan yang dialami masyarakat hukum adat bahkan sampai kini masih terus terjadi, sekali pun dalam kenyataannya wujud satu sama lain berlainan, tetapi pada dasarnya pelecehan hak ulayat masyarakat hukum adat adalah sejenis, yakni menganggap enteng dan tidak menghormati ulayat masyarakat hukum adat demi untuk kepentingan yang lebih besar, yang katanya bersifat menyeluruh.

Sejak kemerdekaan, UUPA mengakhiri kebhinnekaan perangkat hukum yang mengatur bidang pertanahan, yang didasarkan pada hukum adat dan mengadakan unifikasi hak-hak penguasaan atas tanah, baik hak-hak tanah maupun hak-hak jaminan atas tanah. Pembentukan UUPA dengan berdasarkan hukum adat, memberikan arti sebagai pengakuan terhadap Masyarakat Hukum Adat dan hak ulayat.

Sampai saat ini pengaturan hak ulayat masih tersebar secara sporadik dalam berbagai perundang-undangan di Indonesia. Pengaturan hak ulayat dalam berbagai peraturan perundangundangan masih sebatas pengakuan berupa pengakuan dan penghormatan hak ulayat dari masyarakat tersebut (pengakuan dengan pembatasan), yang semuanya dilakukan dengan tujuan 
untuk memberikan perlindungan hukum terhadap hak ulayat. Tetapi menjadi tidak jelas dan menimbulkan penafsiran yang tidak memadai dengan tujuannya, bahkan sering meniadakan dari merugikan hak masyarakat hukum.

Pengakuan yang secara formal diakui dalam perundang-undangan tidak pernah diimplementasikan, sehingga tetap saja tidak ada perlindungan hukum, karena kalua terjadi suatu konflik baik antara pemerintah dengan masyarakat hukum adat atau antara pengusaha dengan masyarakat, ujung-ujungnya adalah suatu kenyataan yang pahit diterima oleh masyarakat hukum adat, tidak adanya keberpihakan dan sering meniadakan haknya. Dan itu pun merupakan pelecehan terhadap hak ulayat masyarakat hukum adat.

Pasal 3 UUPA mengandung pernyataan pengakuan mengenai eksistensi hak ulayat masyarakat hukum adat sepanjang kenyataannya masih ada, artinya bila dalam kenyataannya ada, hak ulayat itu tidak akan dihidupkanlagi, dan tidak akan diciptakan hak ulayat baru. Hak ulayat dibiarkanmenurut ketentuan masyarakat hukum adat masing-masing.

Menurut Maria S.W Sumardjono, pembatasan hak di sampingpengakuan sebagaimana tercantum dalam Pasal 3 UUPA para penyusun/pembentuk UUPA lebih didorong oleh pengalaman empiris berupahambatan ketika pemerintah memerlukan tanah yang dipunyai masyarakathukum adat untuk proyek pertanian di Sumatera Selatan menjelang Tahun 1960, yang antara lain membuahkan pokok-pokok pikiran bahwa kepentingan masyarakat hukum adat harus tunduk kepada kepentingan nasional dan bahwa hak ulayat tidak bersifat eksklusif.

Kehilangan saksi atau pelaku sejarah. Para tokoh adat merupakan kelompok orang yang paling mengetahui keberadaan tanah adat. Mereka merupakan saksi atau pelaku sejarah. Dalam penentuan keberadaan tanah adat kehadiran tokoh adat sangatlah penting. Para tokoh adat tidak hanya sebagai kelompok yang turut menentukan batas-batas tanah adat, tetapi mereka juga merupakan kelompok pejuang yang berusaha untuk mendapatkan tanah adat, baik melalui perang antara suku.

Umumnya luas tanah adat ditentukan melalui suatu keputusan bersama antara tokoh adat dari beberapa desa yang termasuk bagian dari Kecamatan Pangururan. Keputusan lisan ini secara adat memanglah kuat karena sering dibuat melalui suatu perjanjian adat yang disertai dengan korban hewan sebagi perjanjian.

Perjanjian ini dalam hukum adat ini mempunyai keharusan yang harus ditaati dan semestinya tidak boleh dilanggar oleh kelompok yang terlibat dalam perjanjian tersebut. Tetapi karena perjanjian adat dilaksanakan secara lisan dan bukan tertulis kemudian perjanjian ini dimanipulasi. Ada kelompok masyarakat tertentu yang sengaja menghilangkan jejak batas tanah adat yang sudah disepakati bersama sejak leluhur. Atau karena batas tanah adat adalah gunung, sungai, atau bukit dan pohon tertentu kemudian batas tersebut sudah tidak saling mengakui.

Karena hilangnya saksi dan pelaku sejarah, setiap orang yang tidak mengetahui secara pasti keberadaan tanah adat dapat tampil untuk memberikan kesaksian tentang keberadaan tanah adat menurut pandangannya sendiri, yang tentu saja kebenarannya sangat diragukan. Dalam pemberian bukti keberadaan tanah adat ini tidak jarang kelompok masyarakat tertentu menyampaikannya melalui nyanyian adat pada upacara adat. Dalam nyanyian ini disebutkan nama tempat wilayah kekuasaan marga orang batak. Tujuan selain untuk mengingatkan kepada generasi muda tetapi mau menunjukan bahwa marga yang bersangkutan adalah orang pertama dan asli yang memiliki tanah marganya dan merupakan orang pendatang. Selain itu melaui cerita dongeng yang mempunyai nilai sakral dan diceritakan pada saat upacara adat. Di dalamnya memuat cerita tentang kehebatan atau kekuatan marga dalamberperang merebut tanah suku, atau ketika pertama kali suku tersebut datang dan menempati suatu daerah yang kemudian menjadi kampung halamannya dan menjadi wilayah kekuasaannya.

Dengan hilangnya saksi sejarah serta lemahnya pemahaman masyarakat adat mengenai nilai budaya, hukum dan Perundang-undangan, Pemerintah, Ketua-Ketua suku dan tokoh masyarakat adat dapat memberi pemahaman melalui sosialisai nilai budaya, hukum dan perundang-undangan tersebut. 
Dalam kasus tertentu lemahnya pemahaman masyarakat adat tentang status tanah adat ini, digunakan oleh kelompok penguasa untuk mengambil tanah-tanah masyarakat dengan klaim sebagai tanah Negara dan akan digunakan untuk kepentingan umum. Para tokoh adat pun sering tidak memberitahukan tentang keberadaan tanah yang dimiliki oleh masyarakat adat kepada seluruh masyarakat tertentu menggarap atau mengolah tanah di luar kuasa ulayatnya, dengan tanpa memberitahu atau mendapat izin dari kelompok masyarakat yang berhak atas tanah adat yang digarapinya.

Penetapan letak tepat bidang tanah merupakan salah satu yang sangat menentukan nilai kepastian hukum hak atas tanah yang terdaftar. Kepastian obyek hak ini meliputi letak dan batasbatas bidang tanah yang dilekati suatu hak di atasnya. Terkait dengan kepentingan tersebut tersedianya Peta Dasar Pendaftaran Tanah sangat diperlukan, terutama untuk memastikan letak tepat sebidang tanah yang sudah dilekati suatu hak, serta keberadaan bidang-bidang tanah lainnya, baik yang sudah terdaftar maupun yang belum terdaftar (Ridwan \& Muazzul, 2019).

Ragam status tanah sendiri seperti di antaranya; Tanah Hak Milik Adat, Tanah Swapraja dan Bekas Swapraja dan Tanah Negara. Terhadap tanah-tanah yang memiliki status demikian berdasarkan UUPA dapat diberikan haknya, tetapi untuk dapat memberikan jaminan kepastian hukum, maka pendaftaran tanah yang dilakukan terhadap status tanah tersebut secara materil harus sesuai dengan tata laksana pendaftaran tanah sebagaimana mestinya.

\section{SIMPULAN}

Aturan hukum pendaftaran tanah untuk pertama kali bagi hak milik atas tanah adat adalah sebagai berikut: Undang-Undang No. 5 Tahun 1960 tentang Peraturan Dasar Pokok-pokok Agraria: Undang-Undang ini lebih dikenal dengan sebutan Undang-Undang Pokok Agraria (UUPA). Menurut ketentuan Pasal 1 angka 1 PP No. 24 Tahun 1997 adalah serangkaian kegiatan yang dilakukan oleh pemerintah secara terus-menerus, berkesinabungan dan teratur, meliputi pengumpulan, pengolahan, pembukuan, dan penyajian serta pemeliharaan data fisik dan data yuridis, dalam bentuk peta dan daftar, mengenai bidang-bidang tanah dan satuan-satuan rumah susun, termasuk pemberian surat tanda bukti haknya bagi bidang-bidang tanah yang sudah ada haknya dan hak milik atas satuan rumah susun serta hak-hak tertentu yang membebaninya.Hak Pengelolaan dapat berasal dari Tanah Negara dan Tanah Ulayat. Hak Pengelolaan yang berasal dari Tanah Negara diberikan kepada instansi Pemerintah Pusat, Pemerintah Daerah, badan usaha milik negara/daerah, badan hukum milik negara/daerah, badan bank tanah dan badan hukum yang ditunjuk oleh Pemerintah Pusat. Sedangkan Hak Pengelolaan yang berasal dari Tanah Ulayat ditetapkan kepada masyarakat hukum adatPelaksanaan Pendaftaran Hak Milik Atas Tanah Adat Pada Kantor Pertanahan Kabupaten Samosir: menyiapkan dokumen persyaratan, membuat dan menyampaikan surat permohonan, membayar biaya permohonan; Pengukuran dan pemeriksaan tanah pemohon, PengumumanMembuat pengmuman melalui berita harian umum dengan jangka waktu selama 60 (enam puluh) hari, Penerbitan surat keputusan (Kantah, Kanwil, atau BPN RI ), Pembukuan hak dan penerbitan sertifikat.Kendala yang dihadapi oleh pegawai Atr-Bpn kabupaten samosir dalam pendaftaran tanah untuk pertama kali untuk hak atas tanah adat adalah Batas tanah adat yang tidak jelas;Adanya Klaim dari Negara atau Pemerintah;Kehilangan saksi atau pelaku sejarah.

\section{DAFTAR PUSTAKA}

Amiruddin. (2006). Metode Penelitian Hukum. Bandung: PT. Citra Aditya Bakti.

Amiruddin. (2018). Pengantar Metode Penelitian Hukum. Depok: PT. Raja Grafindo Persada.

Anatami, D. (2017). Sekilas Tentang Hukum Jaminan, Hak Jaminan, Hak Tanggungan, dan Eksekusi Hak Tanggungan. Yogyakarta: CV. Budi Utama.

Arba. (2019). Hukum Agraria Indonesia, Jakarta: Sinar Grafika.

Asmah. (2018). Pengantar Hukum Indonesia Suatu Pemahaman Awal Mengenal Hukum. Yogyakarta: UII Press.

Diantha. (2019). Metodologi Penelitian Hukum Normatif Dalam Justifikasi Teori Hukum. Jakarta: Prenada Media Grup. 
Dyara, R. (2018) Panduan Mengurus Tanah Rumah dan Perizinannya. Yogyakarta: Legality.

Lubis, M. Y. (2019). Pencabutan Hak, Pembebasan, dan Pengadaan Tanah. Bandung: CV. Mandar Maju.

Lubis, Y. (2017) Hukum Pendaftaran Tanah. Bandung: Mandar Maju.

Muchsin, (2019) Hukum Agraria Indonesia dalam Perspektif Sejarah. Bandung: PT. Refika Aditama.

Mudakir, I. (2019) Panduan Mengurus Sertifikat dan Penyelesaian Sengketa Tanah. Jakarta: Bhuana Ilmu Populer.

Muhammad, Y. (2014). Panduan Bantuan Hukum di Indonesia. Jakarta: Yayasan Obor Indonesia.

Nasution, B.J. (2008). Metode Penelitian Ilmu Hukum. Bandung: C.V Madar Maju.

Ridwan., \& Muazzul. (2009). Pelaksanaan Pengawasan terhadap Penyalahgunaan Ijin Tinggal oleh Penyidik Imigrasi di Kota Medan, Mercatoria, 2 (2): 104-112

Sembiring, R, Hukum Pertanahan Adat, Raja Grafindo Persada, Depok, 2017.

Simanjuntak. (2015) Hukum Perdata Indonesia, Jakarta: Prenada Media Group.

Soerojo, W., (2004). Pengantar dan Asas-asas Hukum Adat. Jakarta: CV. Haji Masagung.

Urip, S. (2010). Pendaftaran dan Peralihan Hak atas Tanah. Jakarta; Prenada Media Group.

Zulyadi, S. (2020). Kerangka Teori Dalam Penelitian Hukum. Medan; Enam Media.

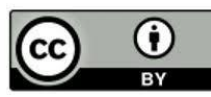

